\title{
Ex post evaluation of developmental interventions in large scale infrastructure projects: The case of Vistonida rural area
}

\author{
Stathakis E., Stambologlou E and O. Manoliadis* \\ Department of Civil Engineering, Democritus University of Thrace, Xanthi, Greece
}

\begin{abstract}
The structural development interventions carried out by the European Union (EU) aim to accelerate the real convergence of 28 Member States, mainly those lagging behind interventions. Most of these contribute to better environmental protection, better life condition for farmers and flood protection. Evaluation of infrastructure projects contributing to spatial growth in ex-ante, ongoing, and ex-post basis is an essential activity to answer several issues raised during the growth mentioned above process. This paper aims to evaluate on ex-post basis integrated developmental interventions-large scale infrastructure projects in rural areas, using a combined method based on Social Cost-Benefit Analysis (SCBA), sustainable and rural growth indicators coming from official organizations along with the n-Dimensional $(\mathrm{nD})$ modelling. The studied developmental interventions refer to Vistonida's rural area, an area to which large-scale infrastructure financed and carried out by the Greek state. They contributed to the modernization and adaptation of the agriculture sector, improving its qualitative and quantitative performance. The needed data derived from the Hellenic National Statistical Services, Ministry of Agriculture, Greek Payment Authority of Common Agricultural Policy (C.A.P.) and concern a period of forty years and they are referred to Land redistribution, irrigation land, crops structure. According to this study, the large-scale agriculture infrastructure contributes significantly to the improvement of the growth rates of a rural spatial productive system as a whole. The application of the combined method was simple, easily understood by policymakers, adequately reliable, and precise
\end{abstract}

Keywords: Ex post Evaluation, Sustainable Indicators, large scale infrastructure projects, Sustainability Criteria, Rural Development Projects, Development Interventions

\section{Introduction}

The evaluation of rural infrastructure projects is a significant issue, but there is no standard method that is acceptable by all experts. Many methodological differences exist between countries regarding the scope and process of evaluation of such large-scale infrastructure. The time and international comparison showed which methods are suitable with more strong advantages and which have weak points/disadvantages. Overtime, Cost-Benefit Analysis (CBA) is not the only method used for the ex-post evaluation of rural projects for infrastructure. Still, it is one of the most common practices, easily understandable even by no specialists. When it is combined with other evaluation methods or tools like Multi-Criteria Analysis (MCA) and $\mathrm{n}$-dimensional $(\mathrm{nD})$ modelling produces beneficial and reliable outcomes.

The structural development interventions per every programming period-called long-run strategic development plans have been carried out by the European Union (EU). Development plans aim is to accelerate the real convergence of the 28 Member States, mainly those lagging, and interventions may take the form of a Community Support Framework, an Operational Program, or a Programming Document (European Commission EU 1994, 2000) Convergence is a prerequisite for the successful completion of EU support to infrastructure of a member state is the mobilization and coordinated actions by all its entities involved in the implementation of developmental activities in public and private sectors e.g., all the socioeconomic authorities. A collective national effort is necessary to ensure that there will be a full match between the vast resources available for the implementation of projects and mechanisms to transform 
resources in growth actions in a cost-effective way. On the other hand, the supported member state to avail necessary human resources and management tools capable of effectively carrying out all actions predicted by projects in real activities (Kunz et al, 2002) Evaluation is an essential tool that answers several issues raised via the growth mentioned above process. The fiscal practices aiming to reduce public spending and the classical financial control of how public resources allocated differentiate the evaluation. Also, the evaluation seeks to increase the effectiveness of available resources in every phase. It consists of a dynamic tool of cost-benefit analysis and is extensively used in the decision-making process at both a technoeconomic and socio-political level. The main objective of the evaluation is to assess the effectiveness of structural interventions by EU authorities concerning the goals chosen as they specified by the EU Directives and Guidelines and, to analyze the impact of interventions on the specific structural problems of all the regions of the European Union (Rischmoller et al, 2000),

\subsection{Evaluation of Development Interventions}

Developments interventions in rural areas consist of flood /drainage works and irrigation systems contribute to better environmental protection, better life condition for farmers and flood protection. Every developmental intervention to member states, technical, administrative, educational, or social infrastructures is subject to evaluation. These structural interventions may be evaluated in every planning or implementation stage, that is, on ex-ante, ongoing and ex-post stage, depending on the timing of the evaluation. The basic goal of such evaluations of EU projects is to provide feedback/updated information to decision policymakers and in-depth analysis able to contribute to the most cost-effective implementation and completion of each growth intervention in due time. According to the European Commission's Working Documents, seven distinct modules should be included in the content of EU growth interventions to member states/regions evaluation processes for the evaluations to be perfect, e.g., to give reliable and accurate results:

- Strength Weaknesses Opportunity Threats (SWOT) analysis

- Gap analysis.

- Social Cost-Benefit Analysis (SCBA)

- Assessment of the continuing correctness and validity of the selected development strategy through every kind of infrastructure projects.

- Quantification of spatial inputs/outputs and socio-economic impacts.

- Assessment of effectiveness and efficiency of the expected socio-economic impact on the area and evaluation of the planning growth policies and whether resources allocated in a cost-effective way to financing the new large scale infrastructure.

- Assessment of the effectiveness and efficiency of the quality of institutions to avoid bureaucratic delays in implementation

- Conclusions, comments, and recommendations at each stage, ex-ante and ex-post

Through the $\mathrm{nD}$ Simulation method, all the above may be taken into account during the process of projects evaluation ( The socio-economic evaluation of large spatial projects is based on analytical approaches that take into account all possible impacts on an area after projects implementation. The main methods of a socio-economic evaluation are:

- Efficiency analysis

- Social Cost Benefits analysis

- Cost-Effectiveness analysis

- System analysis

- Gap analysis

\subsection{Impacts on agriculture infrastructure}

From those mentioned above, it has resulted that, the significant projects referred to the agriculture infrastructure have severe developmental impacts on local rural areas because they induce:

- Differentiations in the economic environment and production system of the region 
- Development of networking in productive sectors of the region -

- Promoting more and better opportunities to do business in the agriculture sector

- Promoting the concept of quality in every production process, from field cultivating to the high quality of products and service delivery.

- Protecting and promoting the environment and the cultural heritage

- Enhancing the competitiveness of products and services through better economies of scale and the use of innovative and modern technologies in every production operation

- Improving the use of the new Integrated Circuit (IC) technologies to improve market access for products and services

- Strengthening the local partnership, networking, and cooperation

- A part of infrastructural interventions refer to protection of around environment from malpractices of farmers overdoses of pesticides, fertilizes and implementation of bad practices of water management.

\subsection{Aim of the paper}

In this paper, a combined method based on Social Cost-Benefit Analysis (SCBA) is used as well as sustainable and rural growth indicators coming from official organizations along using $\mathrm{nD}$ modelling. Moreover, the socio-economic impacts have to be measured in any case when important projects are carried out because whatever can be measured, it can be improved. Even this method, along with the use of special indicators in combination with $\mathrm{nD}$ modelling, can give the most reliable and accurate results regarding the contribution of large-scale agriculture projects in the growth and qualitative upgrade of a rural area Little and Mirrlees , 1974). The most important assumption of SCBA is that it is related to the fact that market prices do not represent the real value of the production of indicators used in our combined method. The above are suggested by the World Bank and the United Nations Industrial Development Organization (UNIDO) [6]. The basic goals of this study are two, first, to describe on a quantitative basis the large-scale infrastructure developed the last 16 years in a certain rural area Vistonida and second, to measure and evaluate in depth the impacts of these infrastructures on the economic and social development using a combined method based on SCBA, Sustainable Indicators on spatial level along with the $\mathrm{nD}$ modelling. It is noted that this combined method is carried out in Greece for the first time.

\section{Methodology}

In order to meet the basic goals of this research we have used SCBA, Special Sustainable Indicators related to spatial development in combination with $\mathrm{nD}$ modelling. Show the available data matched very well through the combined method and one can calculate and evaluate the data, resulting in useful quantitative indices and outcomes showing the growth differences between two periods; before and after infrastructures constructing. In order to see the combined method and $\mathrm{nD}$ modelling, a brief presentation of the existing methodologies follows.

Since the SBCA method is very common, and the suggested indicators are standard, the literature review will be referred only to $\mathrm{nD}$ modelling.

The $\mathrm{nD}$ modelling is used to investigate whether large-scale rural infrastructure in a particular area affects, qualitatively and quantitatively, the development of the agricultural sector (merging scattered farmers' fields in 1-2 pieces, flood /drainage works, irrigation systems, etc.). The $\mathrm{nD}$ investigates whether large-scale rural infrastructure has affected rural land towards becoming more beneficial by concentrating the scattered fields, rationalizing and modernizing cultivation methods, enhancing the productivity and competitiveness of rural productive systems, making Irrigation systems more cost-effective and helping to increase the local added value of crops. Also, the method has often been globally used to assess the feasibility and viability of major infrastructure projects [6] Essentially, $\mathrm{nD}$ modelling is a research effort that gains ground and interest all over the world, contributing to its precision and simplicity to planning new development methods and tools by decision-policy makers and with ex-ante, ongoing and ex-post evaluation of infrastructures optimizing their performance. The $\mathrm{nD}$ modelling, as a techno-economic evaluation method of infrastructure sector, highlights both aspects, the technical/technological and economy of scales barriers, and the economic opportunities. It combines the temporal frequency and optical environments along with 3D geometric models (x, y, z axes), and hence it sometimes is referred to as 4D/ CAD method (Richmoller et al, 2000) In 
order for the $\mathrm{nD}$ model that is a geodata planning platform to give the most reliable and accurate results, it has to be provided by the best data and information in time series form.

All the frameworks of the Community Support Frameworks include ever a special part referred to rural development and reconstruction, e.g., a number of actions related to the development of rural areas. Such five projects have been implemented in the Region of East Macedonia and Thrace, and now a new one is running. The planning of the integrated programs was based, first on the European Union's intention to support projects with a sectorial and spatial approach, and second on the strategy for integrated, sustainable and globally competitive rural development. Integrated rural development refers to the sustainability/viability of rural areas and, more specifically, to those functions that, with smart infrastructure and innovative interventions, could upgrade the total agricultural production system. Studying in-depth the relations among all components of the rural production system and interactions among them, plus analyzing their total impact through cost/benefit analysis we can have a better picture of the situation of the rural sector, and we can shape the new developing strategies(Hedrickson,2003)

Viability in the agricultural infrastructure refers to 4 socio-economic dimensions, first to the spatial one, e.g. the field, agribusinesses, regional and country level, second the time one e.g. the pay-back period of infrastructure, third the social one, e.g. the economic, social, cultural and aesthetic cost and benefits, and fourth the environmental one, e.g. the impact of infrastructure on the environment (Panagiotakopoulos, 2007 Stathakis and Bandekas , 2018)

From the above, it results that, the significant projects referred to agriculture infrastructure have serious developmental impacts on local rural areas because they induce:

- Differentiations in the economic environment and production system of the region

- Development of networking in productive sectors of the region

- Promoting more and better opportunities to do business in the agriculture sector

- Promoting the concept of quality in every production process, from field cultivating to the high quality of products and service delivery.

- Protecting and promoting the environment and the cultural heritage Enhancing the competitiveness of products and services through better economies of scale and the use of innovative and modern technologies in every production operation-Enhancing the use of new IC technologies to improve market access for products and services

- Strengthening the local partnership, networking, and cooperation

It is plausible that all the above will be taken into account during the process of projects evaluation through the nD Simulation Method (PMI 2000, Ghassan et al(2007).

\subsection{Social Cost-Benefit Analysis (SCBA)}

The main idea of five approaches underpinning their evaluation is to compare the socioeconomic benefits with the corresponding costs in two different periods, before and after. However, there are some essential differences between them, such as:

- In the efficiency analysis, benefits compare with expenses, in financial terms, and at market prices, and is assessed the maximum net profit. In other words, the positive effects are evaluated on a fiscal basis than on a social and environmental basis.Ekboir 1997, Aylward et al 2001)

- In the social cost/benefit analysis, social benefits are compared with the corresponding social costs in monetary terms, and the maximum net social benefits are assessed. (PMI, 2000)

- In the cost-effectiveness analysis, costs are compared in monetary terms and result in a qualitative /natural basis and not financial. This approach presents significant weaknesses and will have to be used only on a comparative/benchmarking basis (Aylward et al 2001). For example, between two projects 
having the same cost will be chosen, the one that is expected to yield more qualitative benefits (FAO,1997, Belli et al 2001)

- In the system analysis, all benefits and costs are expressed only in qualitative /natural terms. This approach involves an effort to compare systematically on quantitative basis benefits and costs using a reasonable sequence of calculations and estimates, which can monitor and control an expert third-party. We often find this approach with other formalities, such as operation research and cost- usefulness Aylward et al 2001, Dhlohlo 1997)

- Finally, the gap analysis compares the actual, current performance of a productive system with desired, potential performance after the implementation of some infrastructures. Gaps can occur in many aspects of a productive system, its structure, its performance, its productivity, etc. Once someone knows what differences exist, they can implement projects to face these drawbacks. The previous involves defining the problem, well documenting the present situation, finding out what can be fixed, and determining what can't be improved in the near future.

\section{2 nD Multidimensional Modelling}

The issue of $\mathrm{nD}$ multidimensional modelling on the geospatial basis has been dealt with by many researchers. A first relevant issue is the concept of $\mathrm{nD}$ data storage/mining which aims at gathering information on multiple themes in order to be able to search effectively. (Casalli et al 2003) Although the $\mathrm{nD}$ data relates to thematic data mining properties and not to the dimensions of modelling geodata, the correspondence lies in the multi-faceted view of data in an integrated way. For example, nD modelling expands Building Infrastructure Information Models with additional theme features aiming to serve every stage of the life cycle of a building installation through a common information model. However, $\mathrm{nD}$ modeling focuses mainly on the integration of multiple project themes rather than multidimensional concepts. As the multidimensional data model $\mathrm{nD}$ that was proposed provides a framework for the formation of each geoinformation, the thematic approach of $\mathrm{nD}$ can be supported by the developments of multidimensional data modelling that include the time dimension, a very important issue since the model takes into account the value of money. Van Oesterom (2006).

Even, the $\mathrm{nD}$ model supports multicriteria decision-making techniques able to help decision-policy makers and experts to plan and evaluate in advance large-scale projects combining qualitative and quantitative criteria, i.e., criteria based on regulations and standards that cannot be measured directly in their physical form and expressed in geometric dimensions, currency units, months, etc. (Kuntz et al 2002Koutroumanidis et al 2008)

In this context, this work explores both the course of implementation and management so far and the dimension of management tactics and practices between the original objectives and the results of the programs

The analysis became on a spatial level for the specific rural area of Vistonida, where, in the last 16 years, there have been made significant growth interventions and infrastructures to improve the economic and environmental conditions in favour of the local society. The philosophy of the method is to measure the socioeconomic and environmental impacts of certain growth interventions and infrastructures made in the last ten years in the rural area of Vistonida. The growth interventions and infrastructures are land redistribution, new irrigation projects, new agriculture road projects within rural land, crop changes and upgrading on qualitative/ quantitative/productivity basis overtime, vegetation changes on time basis, and impacts on more early or late harvesting. They consisted of the ad hoc indicators used to measure on an exante and ex-post basis the impacts on the sustainable development of Vistonida.

Through the $\mathrm{nD}$ simulation model, interventions and infrastructure impacts have been evaluated and measured so as to see in a real cost/benefit analysis. E.g. to see whether the interventions and infrastructures contributed to the sustainable development of Vistonida.

\section{Sources of Data and Special Indicators}

Data concern the agricultural area located east of Vistonida Lake in Thrace a region in Northeastern Greece and cover an extension of 120.000 stremmas. Almost all agricultural area can be irrigated through 
drill - water. The big problems for the area are the often floods and the bad draining conditions.

The data regarding the crops are referred to a period of 1965 - 2016 while the impacts of new infrastructures economic analysis and respected results referred to two certain periods, 1995 and 2016. The new infrastructure and land consolidation begun in 1995 and completed in 2012.

Firstly, the necessary data for the area of Vistonida were collected, tabulated and arranged for the two welldiscriminated periods of 1995 and 2017.

Secondly, there has been a time/spatial-based multidimensional analysis and evaluation of infrastructures' impact using ad-hoc indicators. Indicators used came from Organization for Economic Co-operation and Development (OECD) is an intergovernmental, the European Environment Organization IRENA (Indicator reporting on the integration of environmental concerns into agricultural policy), the National Center for Environment and Sustainable Development (NCESD), and the Viability of Land Redistribution Indices. Finally, the suggested method is simple, easily understandable by policymakers, very reliable and precise, and the data needed existing in the National Statistical Service, or HELLASTAT. The basic formula/equation of the World Bank and the United Nations Industrial Development Organization (UNIDO) regarding the evaluation of large-scale infrastructures and their ad hoc contribution to the upgrading of total resources using gap analysis and special indicators is given by the equation (Koutroumanidis et al 2002, Stoter et al 2012).

$\mathrm{S}=(\mathrm{E}-\mathrm{Cb})+\mathrm{CW}=\mathrm{E}-\mathrm{C}(\mathrm{b}-\mathrm{w})(1)$

where:

$\mathrm{S}=$ the social well-being or net social benefit $\mathrm{E}=$ the increase in resource availability

$\mathrm{C}=$ the consumption of resource

$\mathrm{b}=$ the weighed factor reflecting the social cost of the increased consumed resources $\mathrm{w}=$ the weighed factor reflecting the benefit of the private sector coming from the real increase of resources

$(\mathrm{E}-\mathrm{Cb})=$ the real increase of resources available to the public sector

$\mathrm{Cw}=$ the increase in social welfare coming from the increase of private consumption.

By solving this equation and using the results as independent inputs in the $\mathrm{nD}$ model, we take the positive/negative gap between the two periods, before the constructing of new large-scale infrastructures and after them.

After that, the implementation of the combined method follows.

\section{Model Implementation- Results}

Before applying our evaluating method for Vistonida area, it was considered appropriate to refer to the views of Stoter (2012) and Ohori (2012) who explain that $\mathrm{nD}$ models and data structures can deal with redundancy and inconsistency issues created by unrelated datasets that are in the same location, but in different time periods (4D) and scales (5D). They suggest the adaptation of the concept of 5D data modelling into each practical application and show how the intermediate models, especially the $2 \mathrm{D}+$ scale, 3D + scale, and 2D + time, have already brought significant improvement compared to the independent 2D / 3D data management on multiple scales. They also claim that significant knowledge can be gained from the integration of additional non-spatial dimensions, such as time and scale, and introduces the use of the generalized maps as a capable model/data structure for representation.

Since they have collected the data of significant projects (greater than $300.000 €$ ) for the rural area of Vistonida and arranged it in tabular form, the next step was to define the proper indicators in order to make the evaluation with the support of $\mathrm{nD}$ modelling method. The indicators used to come from Organizations for Economic Co-operation and Development OECD (1999 \& 2001) and IRENA (Indicator reporting on the integration of environmental concerns into agricultural policy) are:

- the \% change of total and rural local GDP or income

- the time dimension, forecasting payback period and real payback period 
- the cost dimension, forecasting and real paid the cost

- the phases of the project, or the extent to which project management plan carried out greater than $90 \%$ (internal life cycle indicator)

- the crops changes on a qualitative/ quantitative/productivity basis overtime

- the vegetation changes on a time basis, being more early or late harvesting

- A set of 6 additional criteria corresponding to certain cases, beyond the classical ones were used as they are presented in Table 1, Table 2, and Figure 1.

Table1: projects existed up to 2000 and new implemented in the years 1995-2016

\begin{tabular}{|c|c|c|c|}
\hline Infrastructure & 1995 & 2016 & $\begin{array}{r}\text { Changes } \\
\%\end{array}$ \\
\hline Land redistribution in stremmas & 0 & 83.808 & \\
\hline $\begin{array}{r}\text { New net additional income due to } \\
\text { Land redistribution }\end{array}$ & 21.083 .000 & 28.127 .000 & 33,41 \\
\hline $\begin{array}{l}\text { Irrigation project/ systems (new } \\
\text { irrigated land stremmas) Irrigation } \\
\text { Drilling inland area year } 1998\end{array}$ & 0 & $\begin{array}{l}913 / 3.639 \\
\mathrm{hr}\end{array}$ & 25,36 \\
\hline $\begin{array}{r}\text { New net additional income due to new } \\
\text { irrigation systems } € \quad(150 € / \\
\text { stemmas })\end{array}$ & 0 & 1.370 .000 & 1.370 .000 \\
\hline $\begin{array}{r}\text { Agriculture roads projects within the } \\
\text { rural land }\end{array}$ & 0 & 315.000 & 315.000 \\
\hline $\begin{array}{l}\text { New net additional income due to new } \\
\text { agriculture roads (transition to only } \\
\text { one parcel - cost reduction). }\end{array}$ & 100.000 & 34.500 & 65,50 \\
\hline $\begin{array}{r}\text { Forecasting payback period and real } \\
\text { payback period }\end{array}$ & 10 & 20 & 100 \\
\hline $\begin{array}{r}\text { Crops changes in qualitative/ } \\
\text { quantitative/ productivity basis } \\
\text { overtime (hr) }\end{array}$ & 0 & 2.556 & 32,98 \\
\hline $\begin{array}{r}\text { New net additional income/loss due to } \\
\text { Crops changes in qualitative/ } \\
\text { quantitative/ productivity / hr }\end{array}$ & $1.793,1$ & $2.626,4$ & 46,47 \\
\hline Vegetation changes in time basis & $2,11 \%$ & $5,00 \%$ & 136 \\
\hline $\begin{array}{l}\text { New net additional income/loss due to } \\
\text { crops early/late harvesting rating } 1 \text { - } \\
100\end{array}$ & 75 & 83 & 10,7 \\
\hline $\begin{array}{l}\text { The attraction of new domestic } \\
\text { investment in the area is under } \\
\text { improvement through projects }\end{array}$ & 0 & 110 & 110 \\
\hline
\end{tabular}

Sources: 1. Ministry of Agriculture official agro-environmental indicators 2. The European Environment Agency IRENA Business Indicators 3. The National Center for Environment and Sustainable Development 4.The Sustainability Indicators of Land and Forest Merger System 5. Ministry of Agriculture

Table 2: implementing the combined evaluating method based on gap analysis, special indicators, and nD modelling using data of Table 1.

\begin{tabular}{|c|r|r|r|r|}
\hline N & Indicators analysis & $\begin{array}{r}\text { Quantitative } \\
\text { changes }\end{array}$ & $\begin{array}{r}\text { Quantita } \\
\text { tive } \\
\text { value }\end{array}$ & $\begin{array}{r}\text { Price } \\
\text { of } \\
\text { indicat } \\
\text { or }\end{array}$ \\
\hline 1 & Crops & New crops & 35679 & $42,57 \%$ \\
\hline
\end{tabular}




\begin{tabular}{|c|c|c|c|c|}
\hline & $\begin{array}{r}\text { reconstruction/changes } \\
\text { (OECD) }\end{array}$ & & & \\
\hline \multirow{3}{*}{2} & \multirow{3}{*}{$\begin{array}{r}\text { Local additional } \\
\text { income coming } \\
(\mathrm{OECD})\end{array}$} & Gross income & $\begin{array}{c}7.044 .00 \\
0 €\end{array}$ & $33,41 \%$ \\
\hline & & Production cost & $61.000 €$ & $1,00 \%$ \\
\hline & & Net income & $\begin{array}{c}6.983 .00 \\
0 €\end{array}$ & $46.47 \%$ \\
\hline 3 & Damages due to floods & $\begin{array}{r}\text { By estimation } \\
\text { based on previous } \\
\text { incomes before } \\
\text { floods }\end{array}$ & $\begin{array}{l}3.700 .00 \\
0 €\end{array}$ & $\begin{array}{l}492.50 \\
0 €\end{array}$ \\
\hline 4 & $\begin{array}{r}\text { New transportation } \\
\text { infrastructure in rural } \\
\text { area Vistonida } \\
\text { facilitating farmers } \\
\text { (Infrastructure } \\
\text { Sustainability } \\
\text { Indicators) }\end{array}$ & $\begin{array}{l}\text { Cost of private } \\
\text { fields alienation }\end{array}$ & $34.000 \mathrm{~m}$ & $\begin{array}{c}1.082 .4 \\
00 €\end{array}$ \\
\hline 5 & $\begin{array}{r}\text { Accessibility in Salpi } \\
\text { area (Infrastructure } \\
\text { Sustainability } \\
\text { Indicators) Litman } \\
(2007)\end{array}$ & $\begin{array}{l}\text { Changes in paths } \\
\text { time for farmers }\end{array}$ & $0,09 \mathrm{~h}$ & $30,56 \%$ \\
\hline 6 & $\begin{array}{l}\text { Fertilizers use and cost } \\
\text { (OECD and IRENA) }\end{array}$ & $\begin{array}{r}\text { Quantity/ quality } \\
\text { of fertilizers }\end{array}$ & 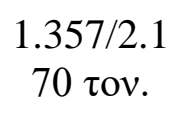 & $60,00 \%$ \\
\hline 7 & $\begin{array}{r}\text { Landscape aesthetic } \\
\text { (OECD) }\end{array}$ & Shannon index & $\begin{array}{c}1.830 / 1.2 \\
58\end{array}$ & $-31 \%$ \\
\hline 8 & $\begin{array}{r}\text { Transforming } \\
\text { farmland into an } \\
\text { ecosystem (Natura } \\
2000) \\
\end{array}$ & $\begin{array}{r}\text { The cultivated area } \\
\text { of Natura } 2000 \\
\text { Treaty }\end{array}$ & $\begin{array}{c}2.513 .91 \\
3 \\
/ 2.787 .83 \\
4\end{array}$ & $-9.83 \%$ \\
\hline 9 & $\begin{array}{l}\text { Forestlands switched } \\
\text { to cultivated lands } \\
(\mathrm{OECD})\end{array}$ & $\begin{array}{r}\text { Loss of vegetation } \\
\%\end{array}$ & $\begin{array}{c}5,00 \% / 2 \\
11 \%\end{array}$ & $+136 \%$ \\
\hline 10 & $\begin{array}{l}\text { Balance of conversion } \\
\text { of arable areas into the } \\
\text { ecosystem (Natura } \\
\text { treaty, etc.) (OECD) }\end{array}$ & $\begin{array}{r}\text { Percentage } \% \text { of } \\
\text { conversable arable } \\
\text { area }\end{array}$ & & $\begin{array}{l}+273 \\
\text { stremm } \\
\quad \text { as }\end{array}$ \\
\hline & Number of fields/ & Number of fields & $5.74 / 1$ & $17.41 \%$ \\
\hline 11 & $\begin{array}{r}\text { farm before and after } \\
\text { rural land } \\
\text { redistribution (Land } \\
\text { consolidation } \\
\text { Indicators) }\end{array}$ & Number of rights & $7.69 / 1$ & $13.00 \%$ \\
\hline 12 & $\begin{array}{r}\text { Average extent in } \\
\text { stremmas/ farm } \\
\text { business (Land } \\
\text { consolidation } \\
\text { Indicators) } \\
\end{array}$ & $\begin{array}{r}\text { Farm business \% } \\
\text { > extend of average } \\
\text { Farm business \% } \\
\text { <extend of average }\end{array}$ & $\begin{array}{l}11,3 \% \\
0,00 \%\end{array}$ & $\begin{array}{l}11,3 \% \\
0,00 \%\end{array}$ \\
\hline 13 & $\begin{array}{r}\text { New crops cultivated } \\
\text { giving higher net } \\
\text { income per stremmas } \\
(\mathrm{OECD})\end{array}$ & $\begin{array}{r}\text { Maize } \\
\text { Cotton } \\
\text { Vegetables }\end{array}$ & $\begin{array}{l}57.125,0 \\
0 \sigma \tau \rho .\end{array}$ & $84,57 \%$ \\
\hline
\end{tabular}




\begin{tabular}{|c|c|c|c|c|}
\hline \multirow{2}{*}{14} & \multirow{2}{*}{$\begin{array}{r}\text { Land redistribution } \\
\text { technical criteria } \\
\text { (Land consolidation } \\
\text { Indicators) }\end{array}$} & $\begin{array}{r}\text { Reduction index } \\
(\mathrm{RI})\end{array}$ & ---- & 2,88 \\
\hline & & $\begin{array}{l}\text { Consolidation } \\
\text { coefficients }(\mathrm{CC})\end{array}$ & ------- & $83,13 \%$ \\
\hline \multirow[b]{3}{*}{15} & \multirow{3}{*}{$\begin{array}{r}\text { Shape of land } \\
\text { redistributed } \\
\text { consolidated field (the } \\
\text { more quadrangle, the } \\
\text { higher marking) (Land } \\
\text { consolidation } \\
\text { Indicators) }\end{array}$} & Total Edges (TE) & $3.418,50$ & 768,82 \\
\hline & & Edge Density (ED) & 850,74 & 208,33 \\
\hline & & Shape Index (SI) & 1,28 & 1,13 \\
\hline \multicolumn{5}{|c|}{$\begin{array}{r}\text { Weighted average price of indicators } \\
24,6 \%\end{array}$} \\
\hline
\end{tabular}

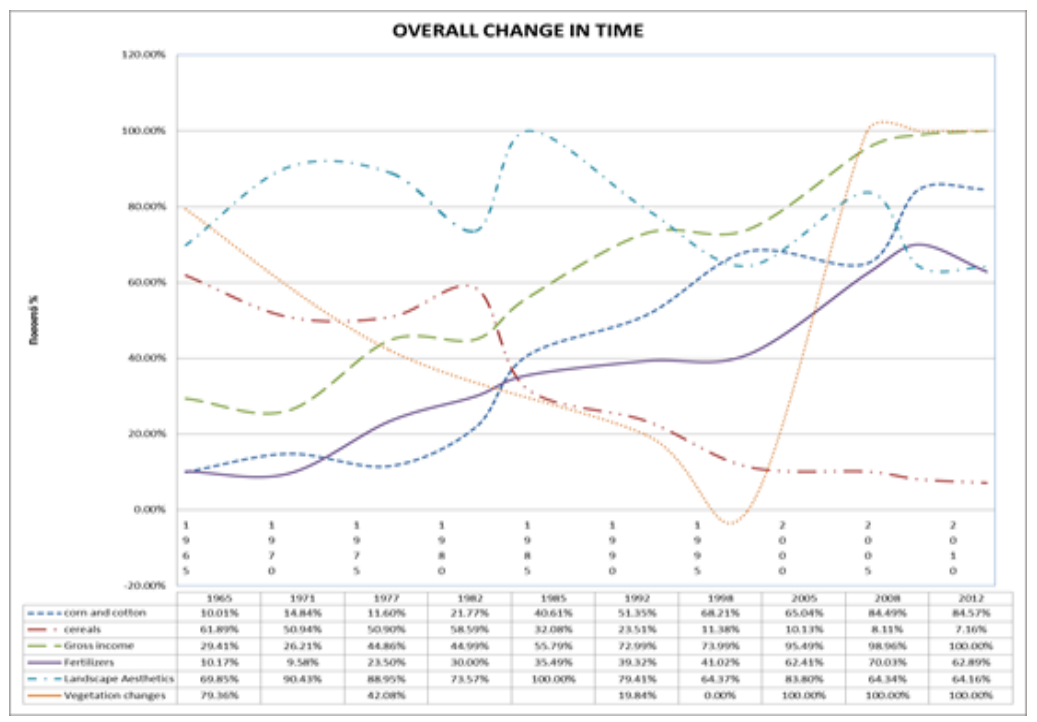

Figure 1: The overtime impacts of large-scale projects/ infrastructure on the rural area of Vistonida The following results are driven by this research:

- As one can see from Figure 1, the rural income has significantly increased from 1995 to 2012, and it means that the crop restructuring goal has been achieved in the best way. Corn and cotton crops have reached about $85 \%$ of the total rural area, so the goal was achieved $100 \%$, essentially tending to become monocultures. Namely, the two basic goals of the Greek Developmental Master Plan for country and the ad hoc rural development program were achieved at a satisfactory degree. The entire crop restructuring amounts to $42.57 \%$, also a satisfactory development.

- The goal of reducing the area cultivated with cereals and correspondingly increasing the area cultivated with industrial and fodder plants was achieved by a $85 \%$. The area cultivated with cereals was reduced and now covers less than $10 \%$ of total farmland, and cereals were replaced by new dynamic crops .As it is foreseen in the feasibility study, the cereals to be limited up to $20 \%$ of total farmland.

- The goal of increasing annual farmers' income per/stremmas, or productivity, due to the construction of new infrastructure was achieved by a $92,40 \%$. The gross agricultural income increased by $€ 90.00$, or $33,41 \%$ due to new infrastructure, while the net agricultural income increased by $46,47 \%$, e.g., the target was overbalanced by $6,03 \%$. The Figure 1 shows the overtime evolution of gross farm income, and it is taken as the reference year 2012 when we had the highest percentage yield achieved.

- Flood-induced damages have significantly reduced, due to the new drainage and flood-preventing infrastructure constructed. More certain it is reduced from 3.700 .000 to $492.500 €$, or $87 \%$.

- Accessibility to the certain rural area has increased for all farmers-so the farm products and equipment transportations were decreased significantly, a 30,56\%. 
- The landscape's aesthetic value has been downgraded due to the monoculture of maize and cotton that have homogenized the surroundings. It is expressed as a percentage $\%$ of the maximum index that has been achieved, is $-31,00 \%$.

- The vegetation has significantly increased in the rural area, mainly due to the cultivation of drainage channels. The percentage $\%$ of natural vegetation has more than doubled, to $136 \%$ improvement.

- The goal of increasing the protected area under the name "Natura 2000 Treaty" (Parker , 2012). The target for increasing the expanse of the «Natura 2000 Treaty» was increased by $9.83 \%$.

- There was a reduction in the multiplicity of the cultivated area per farmer due to the redistribution process, is amounted to $83,00 \%$ (Consolidation coefficients).

- The goal for farmland redistribution in order to be reduced the fields per farm business was achieved from 3 to 1 . Certainly, in average terms, the number of fields per farm business was reduced by one against 2,88 (reduction Index) or by $65,3 \%$. The best case is the Polyanthos farm-block where fields per farm business were reduced by one against 5,7 or by $82,5 \%$

One can categorize the following results according to the following criteria:

Crops restructuring: The long-term goals provided by a 5-years rural growth plan regarding the restructuring of the type of crops cultivated have been achieved by almost $95 \%$.

Increase of gross and net agricultural income: The long-term goals provided by a five-years rural growth plan regarding the increase of gross and net agricultural income achieved by $102 \%$.

Identifying and mitigating the risks and consequences of climate change: All the flood infrastructure was reevaluated, and the malfunctioning problems were identified and repaired.

New transportation infrastructure within the rural area: Exempt the very little existed rural roads new ones were design and constructed reaching $315 \mathrm{~km}$, into the period under study and so that now there is a great improvement in farmers' transportation conditions. It is noted that $34,4 \mathrm{~km}$ additional, exempt $315 \mathrm{~km}$ new roads, with asphalt connecting the villages located within the area under study. The new road system offered better and cost-effective access of farm owners to their fields and villages. The financial and social benefits of such infrastructure were great.

Greater use of fertilizers: The purpose of fertilizers in the rural area from one hand increased significantlyby $76,40 \%$ the productivity of crops. Hence, it had economic benefits. Still, on the other hand, it has adverse environmental and social impacts

Negative impact on landscape aesthetic: the achieved monoculture with maize and cotton, beyond the positive economic impacts, results in a significant negative impact on the ecological and aesthetic value of the rural landscape.

The vegetation has significantly increased in the rural area: It was calculated, the change in the rate of vegetation (natural forest) over time. It was found that while there was a decrease in natural forest up to and including pre-construction time, in post-construction time vegetation was increased from $2,11 \%$ to $5 \%$ of the total area. The obvious environmental benefits come from the vegetation that stabilizes the drainage area, minimizes erosion and helps to be filtered the pollutants before they result to water tanks.

Better balance between farmland and ecosystem: In any case, the stated goal for increased for farmland by $10 \%$ was achieved since it was increased by $9,83 \%$. The farmland redistribution impacts: This goal was achieved by $65,30 \%$, contributing to be reduced the number of fields per farm business, from 3 to 1. Certainly, in average terms, the number of fields per farm business was reduced by one against 2,88 or by $65,3 \%$. The best case is the Polyanthos farm-block where fields per farm business were reduced by one against 5,7 or by $82,5 \%$

Financial and social benefits: The good financial results came from the great reduction of damages of relative infrastructure, and the social ones came from ensuring a better quality of life and a safer environment. The financial and social benefits of such infrastructure were great.

\section{Discussion}

The assessment and evaluation of new infrastructure projects in certain rural areas is a rather complex process because it involves a considerable degree of uncertainty, stochasticity, and risk and is based on a 
number of likelihood working hypotheses- more are stochastic due to climate impact sand hence requires a deep understanding of the total project environment. Yet, the evaluation of new infrastructure projects in rural areas with the existence of many alternatives having various opportunities cost, hence able to offer equal or better exploitation of scarce resources for social benefit, requires big attention. At the planning stage many parameters have to be taken in account such as, cost-benefit assessments, impacts on the human and natural environment, maximization of positive economic outcomes for local communities and the country, the achievement of social goals such as income growth, new qualitative jobs, improvement of access, etc. According to global literature and experience there are two types of evaluation of large-scale projects for infrastructure in rural areas, the financial one where the evaluation focuses on the cash inputs/outputs of the project and the socio-economic one called social cost / benefit analysis that in combination with the $\mathrm{nD}$ modelling method produces rather more accurate results since it focuses simultaneously on the economic benefits and social well-being Natura 2000 That's why in this research the second one is chosen because it is considered more appropriate for large-scale agricultural projects and also because it is flexible since it can evaluate projects through whatever information is available on a spatial basis. The resulted outputs are beneficial for agriculture policy decision-makers of the region of East Macedonia-Thrace to which the Vistonida area belongs.

\section{Conclusions}

Conclusively, this paper aimed to an ex-post evaluation and technical-economic assessment of the projects planned and comprised as growth activities-projects by the plans in the rural area of Vistonida, in relation to the resources available for such projects. Through the Social Cost-Benefit Analysis method along with the $\mathrm{nD}$ modelling and ad-hoc use of indicators propose by official organizations like, OECD, European Agricultural and Environmental Commission (EAEC), the IRENA Agro-Environmental, National Environmental Center and Sustainability indicators, were investigated whether the goals set by long-run growth projects were achieved. Also, it was measured and calculated the certain impacts of infrastructure understudy to certain cases-land redistribution, crop reconstruction, financial and social benefits for the farmers of the rural area, production system sustainability, the environmental protection and water irrigation management.

Specifically, in terms of Crops restructuring the cultivation of maize, cotton, and forage crops has increased, with a great reduction in the area cultivated with cereals. This development contributed to be increased employment and income per stremmas a farm-business, but at the same time, environmental problems were produced due to the overuse of fertilizers, pesticides, over irrigations and landscape uniformity. The longterm interventions encourage young farmers to remain in the agriculture sector, enjoying comparable income to other economic sectors. As for Identifying and mitigating the risks and consequences of climate change all the flood infrastructure was reevaluated, and the malfunctioning problems were identified and repaired.

Regarding the economic benefits the good results came from:

a. The increase of farmers income and land performance

b. The degrees of farmers' production cost

c. The great reduction of damages to crops due to new proper infrastructure

Regarding the social benefits they came from:

a. The better living conditions for farmers'

b. The safer and better-protected environment of Vistonida area

Regarding the good environmental impacts and benefits they came from:

a. The increase of vegetation in the Vistonida area

b. The better balance of farmland between arable and not arable uses

Regarding the negative environmental impacts and benefits they came from:

a. The greater use of fertilizers

b. The greater use of irrigation water

c. The landscape uniformity

Finally the agricultural growth policymakers have to pay more attention when they plan large scale 
agricultural infrastructure projects for better social-economic results, better environmental protection for better living condition for farmers and better flood protection

\section{References}

[1] Aylward B, Berkhoff J, Green C, Gutman P, Lagman A, Manion M, Markandya A, McKenney B, Naudascher-Jankowski K, Oud B, Penman A, Porter S, Rajapakse C, Southgate D and Unsworth R (2001) Financial, Economic and Distributional Analysis p. 168.

[2] Belli P, Anderson J, Barnum H, Dixon J and Tan J-P (2001) Economic Analysis of Investment Operations. Analytical Tools and Practical Application, Washington D.C.: World Bank Institute

[3] Casali A, Cicchetti R, and Lakhal L (2003) Extracting semantics from data cubes using cube transversals and closures. 9th ACM SIGKDD international conference on Knowledge discovery and data mining. New York: ACM Press, pp. 69-78.

[4] Dhlodhlo R (1997) Assessment of the socio-economic impact of irrigation development in Zimbabwe: A Case studies of Hama Mavhaire, Hoyuyu 5, and Nyaitenga irrigation schemes. Paper prepared for the Food and Agriculture Organization of the United Nations, Sub-regional office of Southern and Eastern Africa, Harare.

[5] Ekboir J. M. (1997) “Technical Change and Irreversible Investment under Risk", Agricultural Economics, 16(1), pp. 54-65..

[6] European Commission EU (1994), “Community Structural Funds, GREECE - Community support frame-work 1994-1999 Objective 1: development and structural adjustment of agriculture, Brussels

[7] European Commission EU (2000), "Indicators for the integration of environmental concerns into the com-mon agricultural policy”, COM (2000) Declaration of European Commission to the Council and the Euro-pean Parliament, Brussels.

[8] European Commission EU (2004), "Report From the Commission Annual Report of the Instrument for Structural Policy for Pre-Accession (ISPA), Brussels, 29.10.2004 COM (2004) 735 final

[9] FAO (1997),"Guidelines for the Preparation of Agricultural Investment Projects", Centre of d' investisse-ment, Rome Honeycutt, L. (1998) Communication and Design Course.http://dcr.rpi.edu/commdesign/class1.html

[10] Ghassan A., Lee A and Wu S (2007), "Constructing the Future, nD Modeling”, Editor Taylor\& Francis: London and New York. Pp.17-32.

[11] Hendrickson C (2003), "Project Management for Construction: fundamental concept

[12] Infobank Hellastat SA available at greece.greekreporter.com/tag/infobank-hellastat-sa

[13] Koutromanidis Th, Giatas N, Nakou I, Manos B (2002), "Multicriteria analysis of inputs/outputs of the primary sector in the countries of the European Union" Proceedings of the 7th PanHellenic Conference of ETAG, Athens, pp.43-55.

[14] Kunz J., Fischer M., Haymaker J and Levitt R (2002) "Integrated and Automated Project Processes in Civil Engineering: Experiences of the Center for Integrated Facility Engineering at Stanford University", report \#132, Proceedings from the Specialty Conference on Fully Integrated and Automated Project Processes, Anthony Songer and Paul Chinowsky (Eds.), ASCE, Reston, Jan 2002, pp.96-105.

[15] Litman T. (2007), Measuring transportation: Traffic, mobility and accessibility, ITE Journal, 73(10), $28-32$.

[16] Little I.M.D and Mirrlees J. A. (1974), "Project appraisal and planning for developing countries", New York: Basic Books

[17] Natura 2000 Treaty available at ec.europa.eu/environment/nature/natura2000/management

[18] Ohori, K. A (2012). Developing 5D spatial models for GIS. GIN Symposium, 15November 2012(4 p.).Apeldoorn.

[19] Organisation for Economic Co-operation and Development (OECD) (1999), Oecd Environmental Indicators For Agriculture, Volume 1 Concepts and Framework, Paris

[20] Organisation for Economic Co-operation and Development (OECD) (2001), Environmental Indicators for Agriculture: Methods and Results, Volume 3, p.30-32, Paris 
[21] Panagiotakopoulos D.(2007), "Sustainable Solid Waste Management”, Thessaloniki: Zygos

[22] Parker, C (2012) "Scoping approach and measuring the impact of indexing unit cost parameters in cost-benefit analysis" NZ Transport Agency research report 492, pp 68-72, ISBN 978-0-478-394689

[23] Project Management Institute PMI (2000) "A guide to the project management body of Knowledge", Penn-sylvania: Project Management Institute

[24] Rischmoller L, Fisher M, Fox R, and Alarcon L (2000), “4D Planning \& Scheduling: Grounding Construc-tion IT Research in Industry Practice", Proceedings from CIBW78 Conference on Construction IT, Rey-kjavík, Iceland, pp. 28-30

[25] Stathakis E, Bandekas D (2018) "Thrace Region 1976-2014: 40 years of ineffective regional development strategies", Komotini Greece: Paratiritis

[26] Stoter J., Ledoux H, Meijers M, Arroyo Ohori K and van Oosterom P. (2012) "5D Modellingapplication and advantages", Proceedings from Geospatial World Forum, Amsterdam, Nederland, 23-27 April 2012.

[27] Van Oosterom P. (2006) «Variable-scale Topological Data Structures Suitable for Progressive Data Trans-fer: The GAP-face Tree and GAP-edge Forest.» Cartography and Geographic Information Science, Vol 32 (No 4), pp.331-346. 